\title{
NILAI RELIGIUS DALAM LIRIK LAGU MELAYU JAMBI \\ PADA ALBUM MAYANG MANGURAI KARYA SYAHRIL JAHARI
}

\author{
Mhd. Redho Kurniawansyah ${ }^{1}$ \\ Program Studi Pendidikan Bahasa dan Sastra Indonesia, \\ Fakultas Keguruan dan Ilmu Pendidikan, Universitas Batanghari, \\ Jambi
}

Mhd.redhokurniawansyah@gmail.com

\begin{abstract}
This research aims to describe the aspects of faith between human and God (Hablumminallah) which is found in Jambi Malay song lyrics on the album Mayang Mangurai by Syahril Jahari. The type of research used in this research is qualitative descriptive. The data of this research is the lyrics of Jambi Malay songs on the album Mayang Mangurai by Syahril Jahari. The data shows that each of the song lyrics signified the quotation of religious values relating to the relationship of human with God (Habluminallah). Based on the analysis, it can be seen that there are several aspects found in that song lyrics in which 28 quotations derived from the aspect of faith in God. This represents how people have faith in God. Based on the analysis, it can also be concluded that the lyrics of Jambi Malay songs on the album Mayang Mangurai by Syahril Jahari contain religious values related to human relationship with God (Hablumminallah) from the persepctive of God's blessing towards human being.
\end{abstract}

Keywords: Religious Values, Hablumminallah, Jambi Malay Song Lyric

\footnotetext{
${ }^{1}$ Mahasiswa Program Studi Pendidikan Bahasa dan Sastra Indonesia, Fakultas Keguruan dan Ilmu Pendidikan, Universitas Batanghari, Jambi

Nilai Religius dalam Lirik Lagu Melayu Jambi pada Album Mayang Mangurai Karya Syahril 


\section{PENDAHULUAN}

Karya sastra merupakan ungkapan perasaan seorang sastrawan.. Karya sastra itu ekspresi yang lahir dari pemikiranpemikiran dan perasaan-perasaan serta persepsi-persepsi seorang sastrawan yang dibalurnya dengan daya imajinasi, hingga melahirkan suatu karya sastra (Wiyatmi, 2009: 18). Selain itu, sebuah karya sastra mengadung nilai-nilai luhur yang dapat dijadikan pedoman dalam kehidupan bermasyarakat. Menurut Rahima (2017:1) Kelahiran sebuah karya sastra bersumber dari kehidupan yang bertata nilai dan dapat memberi sumbangan bagi terbentuknya tata nilai dalam suatu masyarakat.

Salah satu karya sastra yang banyak diminati masyarakat adalah lagu, karena menikmati lagu tidak di batasi usia. Penikmat lagu mulai dari anak-anak hingga orang dewasa. Lagu merupakan salah satu jenis karya seni yang diciptakan oleh pengarangnya sebagai ungkapan perasaan yang mempunya makna tertentu. Dalam lirik-lirik lagu terkandung banyak makna simbolik. Simbol-simbol dalam sebuah lagu sarat dengan nilai-nilai positif seperti nilai religius, moral, sosial, dan nilai budaya dapat berfungsi sebagai sarana pendidikan karakter (Rahima, 2017:251). Penyair dapat menciptakan lagu dari gabungan lirik-lirik lagu berdasarkan hasil imajinasinya. diciptakan oleh seorang penyair.

Bahasa ilmiah dan bahasa seharihari harusnya dihindari dalam penggunaan lirik lagu, justru bahasa yang penuh ambiguitas dan memilki segi ekspresif yang digunakan dalam lirik lagu, sehingga lirik lagu itu menjadi menarik (Awe, 2008: 49)

Nilai-nilai religius dalam lirik lagu dapat membantu manusia akan ingat ke pada Tuhan, karena pada zaman sekarang manusia lebih mementingkan duniawi dari pada akhirat. Hubungan dengan Tuhan (Habluminallah), hubungan antar sesama manusia (Habluminannas), dan hubungan manusia dengan alam (Hablumminallam) tidak pernah lepas di kehidupan masyarakat, karna nilai religius sangat berperan penting bagi kehidupan masyarakat (Sapriani, 2018: 3).

Nilai religius dapat memberikan kesadaran batin untuk berbuat kebaikan dan perlu ditanamkan kesadaran tentang pemahaman dan penghayatan terhadap nilai religius. Pentingnya nilai religius dalam bentuk karya sastra seperti lirik lagu yang bermanfaat untuk menuntun manusia berada dalam tuntunan agama. Dengan lirik lagu yang memiliki nilai religius, pendengar dapat menghayati betapa pentingnya beriman kepada Allah Swt. Salah satu lagu yang memiliki kandungan nilai religius di dalamnya adalah lagu-lagu Melayu Jambi karya Syahril Jahari yang dimuat dalam satu album Mayang Mangurai yang berisi 12 lagu.

Syahril Jahari adalah seorang pencipta lagu kelahiran Batanghari yang sudah banyak menciptakan syair-syair yang memiliki makna religius di dalamnya. Dari syair-syair tersebut kemudian beliau menggubahnya menjadi sebuah lagu yang mengangkat nilai-nilai religius di dalamnya. Lagu-lagu ciptaannya sudah banyak mendapatkan apresiasi dan penghargaan dari berbagai macam ajang cipta lagu yang diikutinya. Penghargaan yang pernah diraih Syahril Jahari yaitu pencipta lagu terbaik dalam mengikuti parade lagu daerah tingkat nasioal, dan penata musik terbaik. Lagu yang di ciptakannya pernah beliau bawa untuk mengikuti ajang besar gendang melayu di Malaysia dan singapura mendapatkan penghargaan terbaik. Di daerah kelahirannya, Syahril Jahari juga membuka Sanggar untuk membagi ilmuilmunya (Rifai, 2019: Wawancara)

Fokus penelitian merupakan satu aspek yang terpenting dalam suatu penelitian. Berdasarkan identifikasi 
masalah di atas, fokus penelitian dalam penelitian ini yaitu menganalisis nilainilai religius hubungan manusia dan Tuhan (Habluminallah) yang meliputi nilai-nilai keimanan, beribadah, bersyukur, bersabar dalam lirik lagu-lagu Melayu Jambi di album Mayang Mangurai karya Syahril Jahari sebanyak 12 lagu.

Berdasarkan fokus permasalahan di atas, maka pertanyaan penelitian ini adalah bakgaimanaha nilai-nilai religius dalam hubungan manusia dengan Tuhan (Hablumminallah) dalam lirik lagu-lagu Melayu Jambi di Album Mayang Mangurai karya Syahril Jahari yang meliputi nilai-nilai keimanan, beribadah, bersyukur, dan bersabar?

Penelitian ini bertujuan untuk mendeskripsikan nilai-nilai religius hubungan manusia dengan Tuhan (Hablumminallah) dalam lirik lagu-lagu Melayu Jambi di Album Mayang Mangurai karya Syahril Jahari meliputi nilai-nilai keimanan, beribadah, bersyukur dan bersabar.

Secara teoretik, penelitian ini diharapkan bermanfaat untuk pelestarian nilai seni tentang lagu-lagu Melayu Jambi ciptaan putra daerah Batanghari (Syahril Jahari).

Secara praktis manfaat penelitian ini sebagai berikut:bagi penyair lagu-lagu Melayu Jambi agar dapat menciptakan karya-karya yang lebih bermutu; dan bagi peneliti selanjutnya diharapkan dapat menjadi dasar pemikiran untuk melakukan penelitian tentang nilai-nilai religius dalam lirik-lirik lagu Melayu Jambi.

Karya"sastra"adalah buah pikiran seseorang pengarang dan perasaan seseorang pengarang dalam usahanya untuk menghayati kejadian-kejadian yang ada di sekitarnya, baik yang dialaminya maupun yang terjadi pada orang lain pada kelompok masyarakatnya."Hasil imajinasi tersebut pengarang ungkapkan dalam karya untuk dihidangkan kepada masyarakat pembaca agar dinikmati,"dipahami dan dimanfaatkan. Karya sastra bukanlah suatu karangan kosong atau khayalan yang sifatnya tidak sekedar menghibur pembaca saja tetapi melalui karya sastra pembaca akan lebih memahami masalah kehidupan. Sebagaimana aspek mimetis, karya sastra merupakan cerminan dari masyarakatnya (Astika, 2014: 1).

Mendeskripsikan ide-ide yang telah diperoleh dari fenomena atau masalah-masalah yang terjadi di sekitarnya merupakan hasil karya sastra dari pengarang. Karya kreatif suatu seni dan bermediumkan bahasa yang tidak absolut adalah karya sastra (Susanto, 2016: 6). "Karya sastra ditulis dengan bahasa yang mudah dipahami oleh pembaca. Karya sastra menggunakan bahasa yang baik, indah, dan sopan.

Pengarang membuat karya sastra untuk menghasilkan suatu karya sastra yang baik. Karya sastra adalah fenomena unik," Ia juga fenomena organik." yang mana di dalamnya penuh serangkaian makna dan fungsi" (Endraswara, 2013: 7). Karya sastra bukan hanya dapat menghibur pembaca saja. Karya sastra banyak mengandung makna dan fungsi dari isi kisah yang terdapat dalam karya sastra.

Karya sastra mencerminkan kehidupan manusia yang memiliki etika budaya yang sangat bernilai. Karya sastra dapat mengubah sikap dan perilaku manusia yang berbudaya menjadi lebih berbudaya lagi. Teks merupakan karya sastra yang tersusun dari bagian-bagian instrinsik yang saling berhubungan. Saling berhubungan inilah yang memberi makna atau nilai kepada unsur-unsur tersebut" (Siswantoro, 2010: 20). Karya sastra merupakan karya yang memiliki unsurunsur pembangun dalam karya sastra. Karya sastra dibuat oleh penulis untuk penikmat karya sastra yang menceritakan tentang kehidupan yang dapat

Nilai Religius dalam Lirik Lagu Melayu Jambi pada Album Mayang Mangurai Karya Syahril 
memberikan makna tersendiri bagi pembaca.

Suatu karya yang indah dan bermakna merupakan karya sastra. Sastra menceritakan pengalaman manusia yang akan dijadikan bahan renungan dan refleksi kehidupan yang bersifat koentensif dengan kehidupan (Ismawati, 2013: 3).

Karya sastra mengungkapkan berbagai macam peristiwa yang terjadi dalam kehidupan. Problematika kehidupan sehari-hari tidak pernah lepas dari karya sastra (Nurgiyantoro, 2012: 1). Dimensi kehidupan manusia selalu berisikan tentang fenomena atau masalahmasalah yang dihadapi oleh manusia. Hal ini dapat dijadikan teladan dan nasihat atau teguran dalam kehidupan manusia sehari-hari.

Berdasarkan pendapat para ahli di atas, dapat disimpulkan bahwa karya sastra merupakan hasil cipta imajinasi manusia yang memiliki ciri keindahan bahasa.

Karya sastra memiliki banyak fungsi yang dapat mengubah pola pikir manusia. Karya sastra mampu membawa pembaca mengambil nilai yang terkandung dalam karya sastra untuk bisa menjadi tuntunan ke depan dalam menjalani hidup, karya sastra memiliki fungsi atau melihat yang baik bagi pembaca. Karya sastra memiliki banyak fungsi dalam kehidupan. Menurut (Rokhmansyah, 2014: 8), karya sastra memiliki lima fungsi yaitu fungsi rekreatif (delectore), didaktif (decore), estesis, moral, dan religius.

Lirik"lagu merupakan susunan atau rangkaian kata yang bernada. Untuk menciptakan lirik lagu tidaklah mudah. Namun, lirik lagu dapat diperoleh dari pengalaman dalam kehidupan sehari-hari dan berbagai inspirasi. Misalnya saat sedang jatuh cinta, saat sedang bahagia, ataupun saat sedang sedih" (Awe, 2003: 67). Lirik lagu dapat diciptakan seorang penyair lagu saat sedang memikirkan sesuatu."

Secara luas,"lirik lagu merupakan ekspresi seseorang tentang suatu hal yang telah dilihat, didengar, maupun dialaminnya. Dalam mengekspresikan pengalamannya, penyair atau pencipta lagu menciptakan daya tarik dan kekhasan terhadap lirik lagunya dengan melakukan permainan kata-kata dan bahasa. Permainan bahasa tersebut dapat berupa permainan gaya bahasa, vokal, maupun penyimpangan makna kata dan diperkuat dengan penggunaan melodi dan notasi musik yang disesuaikan dengan lirik lagunya sehingga apa yang dipikirkan penyairnya akan terbawa oleh pendengar"'(Kurniawan, 2001: 56). Lirik lagu adalah ekspresi seorang penyair yang diciptakan dengan merangkai kata-kata dan bahasa untuk menciptakan daya tarik dalam karyanya.

Lagu dapat digunakan untuk pengobar semangat seperti masa perjuangan, menyatukan perbedaan, mempermainkan emosi dan perasaan seseorang dengan tujuan menanamkan sikap atau nilai yang kemudian dapat dirasakan orang sebagai hal yang wajar, benar, dan tepat. Dengan demikian pilihan kata yang digunakan dalam lirik lagu memiliki makna yang dapat merubah emosi pendengarnya yang diharapkan oleh pencipta lagu tersebut. Lirik lagu yang bernuansa religius akan berpengaruh bagi akidah pendengarnya.

Nilai merupakan sikap dalam keyakinan ataupun perasaan yang diyakini sebagai suatu identitas yang memberikan corak yang khusus kepada pola pemikiran, perasaan, ketertarikan maupun perilaku. Bagi manusia nilai adalah sesuatu yang berguna, penting, atau bermanfaat (Kosasih, 2012: 46). Nilai suatu dasar untuk mengukur suatu hal yang berguna, berharga dan manfaat bagi manusia dalam kehidupan sehari-hari. Nilai dapat 
bermanfaat bagi manusia yang menjalani hidup dengan baik.

Nilai merupakan sifat-sifat penting yang berguna bagi manusia dalam menjalani kehidupan. Melalui interaksi di antara para anggota masyarakat tercipta nilai merupakan konstruksi masyarakat (Abdulsyani, 2015: 50). Nilai merupakan interaksi yang dilakukan individu terhadapa individu lainnya. Konsep nilai religi secara umum mengacu pada tiga istilah yang masing-masing istilah terkait dengan kata religi yakni: religi, religius, dan religiusitas.

Religi merupakan bentuk ketaatan seseorang hamba kepada Tuhan. Religi suatu keyakinan, nilai-nilai, dan normanorma hidup yang dipegangi dan dijaga. Tentang cara pengabdian kepada Tuhan religi merupakan kumpulan aturan-aturan. Bentuk religi berdasarkan pada kepercayaan tentang cara pengabdian kepada Tuhan. Bentuk religi berdasarkan pada kepercayaan kepada Tuhan dan terdiri atas upacara-upacara keagaamaan guna memuja Tuhan tersebut"(Khozin, 2013: 55). Kepercayaan manusia kepada Tuhan dengan memuja Tuhan-tuhan-Nya. Menjalankan seluruh aturan-aturan atau ketetapan yang diperintahkan oleh Tuhan.

Nilai religi merupakan jalan bagi manusia untuk memperoleh konsep kehidupan. Nilai religi dalam karya sastra memberikan karya yang bernilai yang mengandung makna kebenaran."Religion adalah mematuhkan manusia mengerjakan pekerjaan yang perlu dilakukan untuk" keperluan masyarakat. Ikatan manusia dengan manusia dan ikatan manusia dengan Tuhan" (Abdullah, 2006: 3). Nilai religi merupakan nilai yang berkaitan erat dengan hubungan baik manusia dengan Tuhan, dan hubungan baik manusia antar manusia.

\section{METODE PENELITIAN}

"Jenis penelitian berarti cara yang dipergunakan seorang peneliti di dalam usaha memecahkan masalah yang diteliti" (Siswantoro, 2010: 55) Jenis penelitian merupakan cara kerja suatu penilitian dalam memahami objek yang akan diteliti. Penelitian ini menggambarkan tentang analisis sastra.

Dalam suatu penelitian sastra ada beberapa pendekatan dalam menganalisisnya. Perbedaan pendekatan inilah yang kemudian memunculkan adanya berbagai jenis penelitian sastra (Rahima, 2017:1-16). Jenis penelitian yang digunakan dalam penelitian ini adalah jenis penelitian deskriptif yang bersifat kualitatif. Deskriptif merupakan prosedur pemecahan yang diselidiki dengan mendeskripsikan atau melukiskan keadaan subjek atau objek penelitian (lirik lagu) pada saat sekarang berdasarkan fakta-fakta yang tampak atau sebagaimana adanya (Siswantoro, 2010: 56). Deskriptif digunakan peneliti untuk dapat memecahkan masalah yang akan dianalisis untuk mendapatkan hasil analisis yang baik.

"Data adalah sumber"informasi yang akan diseleksi sebagai bahan menganalisis"(Siswantoro, 2010: 70). Data didapatkan dari kumpulan informasi dari sebuah kejadian. "Pada dasarnya data tidak lain adalah"objek penelitian plus konteks"(Mahsun, 2006: 19). Data dalam penelitian ini adalah dari lirik lagu-lagu Melayu Jambi pada album Mayang Mangurai Karya Syahril Jahari. Data diambil untuk dianalisis dari setiap katakata dalam lirik lagu tersebut yang mengungkapkan kutipan nilai-nilai religius yang berkaitan dengan hubungan manusia dengan Tuhan (Habluminallah).

Sumber data terkait dengan subjek penelitian dari"mana data diperoleh"(Siswantoro, 2010: 72). Lagulagu karya Syahril Jahari pada Album Mayang Mangurai merupakan sumber data yang didapatkan oleh peneliti. Pada album Mayang Mangurai terdapat 12 lagu yang berdurasi rata-rata 5 sampai 6 menit. 
Album tersebut dirilis pada tahun 2018 dan dijadikan dalam sebuah kaset. Sumber yang peneliti peroleh dari pencitpa lagu tersebut yaitu Syahril Jahari.

"Teknik pengumpulan data merupakan langkah yang paling strategis dalam penelitian,"karena tujuan utama dari penelitian adalah mendapatkan data"(Sugiyono, 2014: 42). Teknik pengumpulan data adalah langkahlangkah yang digunakan dalam proses penelitian.

"Analisis data merupakan proses memberikan makna"terhadap data yang dikumpulkan" (Tohirin, 2012: 141). Setelah peneliti mengumpulkan data dan mengelompokkan data-data tersebut dari lirik lagu-lagu Melayu Jambi pada Album Mayang Mangurai Karya Syahril Jahari. Peneliti melanjutkan menganalisis data yang telah dikumpulkan."Analisis data dilakukan dengan menjelaskan dalam bentuk deskriptif terhadap masingmasing" data secara fungsional dan rasional"'(Siswantoro, 2010: 81).

\section{HASIL DAN PEMBAHASAN}

Berdasarkan analisis dari data-data penelitian ini, dikethaui bahwa dalam lirik lagu Melayu Jambi pada album Mayang Mangurai Karya Syahril Jahari ditemukan nilai religius yang berkaitan dengan hubungan manusia dengan Tuhan (Hablumminallah) mencakup empat aspek, yakni aspek berimanan, beribadah, bersyukur, dan bersabar. Aspek beimanan ditemukan sebanyak 28 kutipan, aspek beribadah ditemukan sebanyak 19 kutipan, aspek bersyukur ditemukan sebanyak 5 kutipan, aspek bersabar ditemukan 7 kutipan. Kesemua aspek yang berkaitan dengan hubungan manusia dengan Tuhan (Hablumminallah) dalam lirik lagu ini sebanyak 59 kutipan.

1. Aspek Beriman dalam Lirik Lagu Melayu Jambi pada Album Mayang Mangurai Karya Syahril Jahari
Beriman berarti mempercayai bahwa Allah Swt. itu benar-benar ada. Yakin bukan hanya dari ucapan saja melainkan meyakini dari dalam hati. Beriman kepada Allah Swt. adalah meyakini keberadaan Allah Swt. beserta sifat-sifat yang dimilikinya. "Beriman kepada Allah Swt. merupakan dasar utama keimanan, dari sinilah melahirkan ketaatan terhadap yang lainnya" (Muchtar, 2005: 26)."Beriman kepada Allah Swt. orang yang selalu menjalankan semua ajaran yang dituntut dalam hidup beragama. Kutipan-kutipan yang berkaitan dengan beriman terdapat kutipan 28 diantaranya, sebagai berikut. Kutipan 1

"Baju putih elahe tuan Selendang putih" (Zapin Barzah).

Kutipan di atas menyatakan bahwa Baju putih melambangkan pakaian yang suci, bersih dari sisi agama, baik di pakai laki-laki maupun perempuan. Selendang putih melambangkan penutup aurat perempuan. Putih dari sisi agama merlambangkan suci, bersih yang berarti dengan berpakaian sesuai dengan petunjuk dan tuntunan ajaran Islam dapat dijadikan sebagai sarana meningkatkan iman dan takwa kepada Allah $S w t$. Karena sebaik-baik perlindungan badan adalah takwa kepada Allah Swt. Menurut Muchtar (2005: 26) beriman kepada Allah Swt merupakan dasar utama keimanan, dari sinilah melahirkan ketaatan terhadap yang lainnya. Beriman kepada Allah Swt. adalah keyakinan dalam hati yang dianugerahkan Allah Swt. kepada manusia yang tidak ternilai harganya.

Kutipan 2

"Oiii Allah lah kasih elahe tuan Muhammad kasih" (Zapin Barzah).

Kutipan di atas menyatakan bahwa Allah kasih Muhammad kasih merupakan tuturan yang diyakini bahwa Allah Swt. dan Nabi Muhammad benarbenar ada. Seorang hamba harus mengenal Allah Swt., agar ia cinta kepada 
Allah Swt. dan Allah Swt. cinta kepadanya, karena Allah Swt. maha penyayang dan maha segalanya. Begitu juga dengan Nabi Muhammad, bila kita bershalawat mengirim satu shalawat kepada baginda Nabi Muhammad, maka Allah Swt. akan mengirim sepuluh shalawat kepada kita. Kita berada dalam jaminan keselamatan Allah Swt. Menurut Muchtar (2005: 26) beriman kepada Allah Swt. merupakan dasar utama keimanan, dari sinilah melahirkan ketaatan terhadap yang lainnya. Beriman kepada Allah Swt. adalah keyakinan dalam hati yang dianugerahkan Allah Swt. kepada manusia yang tidak ternilai harganya. Beriman kepada Allah Swt. merupakan bentuk peng-esaan terhadap Tuhan yang diwujudkan dari sikap penghambaan terhadap-Nya."Beriman secara bahasa berarti menjadikan sesuatu sebagai satusatunya"(Aziz, 2013: 57).

\section{Aspek Beribadah dalam Lirik Lagu Melayu Jambi pada Album Mayang Mangurai karya Syahril Jahari}

Beribadah merupakan ketaatan, penyembahan, pengabdian, merendahkan diri atas segala dosa-dosa yang di perbuat selama hidup. "Beribadah kepada Allah Swt. merupakan suatu tindakan dengan jalan melaksanakan shalat lima kali sehari semalam" (Khozin, 20013: 111). Orang yang beribadah adalah orang yang mengerjakan perintahnya seperti shalat lima waktu dan menjauhkan larangannya seperti perbuatan yang manjadi dosa. Kutipan-kutipan yang berkaitan dengan beribadah terdapat 19 kutipan diantaranya sebagai berikut.

Kutipan 3

\section{"Baju putih elahe tuan Selendang putih" (Zapin Barzah).}

Kutipan di atas menjelaskan bahwa Baju putih baju yang bersih dari najis untuk menunaikan ibadah shalat, karena baju putih lebih tampak bercahaya dan terang. Jika terkena sedikit kotoran saja maka orang akan yang mengenakannya akan segera mencucinya. Selendang putih merupakan kerudung wanita untuk menutupi aurat, selendang putih merupakan mukenah untuk menunaikan ibadah shalat. Menurut Yusuf (2003: 114) "Beribadah kepada Allah Swt. berarti perbuatan yang dilakukan oleh seseorang sebagai usaha menghubungkan dan mendekatkan diri kepada Allah Swt. sebagai Tuhan yang disembah". Beribadah kepada Allah Swt. merupakan suatu sikap yang mana menunjukkan hubungan yang baik kepada Allah Swt. dengan melaksanakan perintah-Nya.

Kutipan 4

"Dibawak budak elahe tuan tegak sembahyang” (Zapin Barzah).

Kutipan di atas menjelaskan bahwa Dibawak budak tegak sembahyang berarti, anak-anak memakai baju putih untuk melaksanakan shalat, baju putih melambangkan suci dari sisi Agama Islam. Menurut Yusuf (2003: 114) "Beribadah kepada Allah Swt. berarti perbuatan yang dilakukan oleh seseorang sebagai usaha menghubungkan dan mendekatkan diri kepada Allah Swt. sebagai Tuhan yang disembah". Beribadah kepada Allah Swt. merupakan suatu sikap yang mana menunjukkan hubungan yang baik kepada Allah Swt. dengan melaksanakan perintah-Nya. Melaksanakan shalat lima kali sehari semalam merupakan Beribadah kepada Allah Swt. (Khozin, 2013: 111).

\section{Aspek Bersyukur dalam Lirik Lagu Melayu Jambi pada Album Mayang Mangurai Karya Syahril Jahari}

Bersyukur merupakan ucapan terimakasih kepada Allah $S w t$. yang telah memberikan karunia serta rezeki kepada umatnya. "Bersyukur adalah ungkapan terimakasih kita kepada Allah $S w t$. Melaksanakan semua perintah Allah Swt. dan menjauhi semua larangan-Nya, serta memanfaatkan semua yang dianugerahkan

Nilai Religius dalam Lirik Lagu Melayu Jambi pada Album Mayang Mangurai Karya Syahril 
Allah Swt. secara benar" (Muchtar, 2005: 29). Bersyukur merupakan ucapan terimakasih kepada Allah Swt. dan menjalankan perintah seta larangan-Nya. Orang yang bersyukur akan memanfaatkan sebaik-baiknya apa yang telah Allah Swt.berikan padanya. Kutipankutipan yang berkaitan dengan bersyukur terdapat 5 kutipan di antaranya sebagai berikut.

Kutipan 5

"Kalu sembahyang elahe tuan ngampuni doso” (Zapin Barzah).

Kutipan di atas menjelaskan bahwa dengan melaksanakan sahalat maka Allah Swt. akan mengamouni dosa kita, karena taat kepada Allah SWT. Kalu sembahyang ngampuni doso berarti hanya Allah $S w t$. yang bias mengampuni dosa kita Allah Swt. maha segalanya. Bersyukurlah kepada Allah Swt., karena Allah Swt. maha pengampun dan maha pengasih. Menurut Muchtar (2005: 29) Bersyukur artiya orang yang selalu menerima cukup atas apa yang diberikan oleh Allah Swt." Mensyukuri nikmat Allah Swt. merupakan orang yang selalu bersyukur atas rizki yang telah Allah $S w t$. berikan, selalu merasa cukup dengan apa yang telah Allah $S w t$. berikan padanya. Mensyukuri nikmat Allah Swt. berarti menerima semua pemberian Allah $S w t$. kepada manusia (Khozin, 2013: 111).

Kutipan 6

"Mohonlah ampun elahe tuan kepado tuhan" (Zapin Barzah).

Kutipan di atas menjelaskan bahwa Mohonlah ampun kepado tuhan berarti mengakui apa yang telah diperbuat, hanya kepada Allah Swt. kita memohanlah ampun, karena Allah Swt. maha pengampun. Allah Swt. sangat menyayangi umatnya yang taat akan perintahnya, bersyukur atas apa yang deberi Allah Swt. Menurut Muchtar, 2005: 29 "Bersyukur artiya orang yang selalu menerima cukup atas apa yang diberikan oleh Allah Swt. mensyukuri nikmat Allah
Swt. merupakan orang yang selalu bersyukur atas rizki yang telah Allah $S w t$. berikan selalu merasa cukup dengan apa yang telah Allah $S w t$. berikan padanya. Mensyukuri nikmat Allah SWT berarti menerima semua pemberian Allah Swt. kepada manusia" (Khozin, 2013: 111).

4. Aspek Bersabar dalam Lirik Lagu Melayu Jambi pada Album Mayang Mangurai Karya Syahril Jahari

Bersabar menerima cobaan merupakan orang selalu ikhlas dalam menerima cobaan dari Allah Swt. "Bersabar adalah menerima cobaan dari Allah SWT dalam makna tabah, tidak putus asa dalam medapat musibah atau menerima bencana"(Khozin, 2013: 111). Bersabar merupakan ikhlas, tabah dan tidak putus asa dengan cobaan yang menghampirinya. Orang-orang yang sabar akan diberikan pahala oleh Allah $S w t$. dan orang yang sabar diuji oleh Allah $S w t$. sesabar apa dalam menerima ujian tersebut. Kutipan-kutipan yang berkaitan dengan bersabar terdapat 7 kutipan sebagian di antaranya, sebagai berikut.

Kutipan 7

"Hidup dan Mati Ditangan Tuhan

Kepado allah kito memohon" (Kilat Senjo).

Kutipan di atas menjelaskan bahwa Bersabar menghadapi cobaan dan hanya Kepado Allah kito memohon, karena Allah Swt. maha pengampun. Allah Swt. akan menijabah doa umatnya yang bersungguh. Menurut Muchtar (2005: 29) "Bersabar adalah tabah menerima cobaan atau ujian yang diberika Allah Swt. bersabar merupakan ciri-ciri orang beriman. Orang yang beriman akan bersyukur apabila ia mendapat nikmat dan akan bersabar bila ia mendapat cobaan atau musibah. Sabar menerima cobaan adalah mengendalikan diri terhadap peristiwa yang terjadi, baik peristiwa yang disenangi maupun yang dibenci (Effendi, 2006: 67).

Nilai Religius dalam Lirik Lagu Melayu Jambi pada Album Mayang Mangurai Karya Syahril Jahari 
Kutipan 8

"Elok Nian Pintu Dipahat Diukir

Dengan Buatan Tangan Kalulah

Kalulah hidup hendak selamat" (Kilat Senjo).

Kutipan di atas menjelaskan bahwa Jika hidup hendak selamat, maka jauhilah larangan yang dilarang Allah Swt., sabarlah menghadapi ujian dari Allah Swt., karena itu semau untuk menguatkan iman, maka hidup akan selamat dari cobaan. Menurut Muchtar (2005: 29) "Bersabar adalah tabah menerima cobaan atau ujian yang diberika Allah Swt. Bersabar merupakan ciri-ciri orang beriman. Orang yang beriman akan bersyukur apabila ia mendapat nikmat dan akan bersabar bila ia mendapat cobaan atau musibah. Sabar menerima cobaan adalah mengendalikan diri terhadap peristiwa yang terjadi, baik peristiwa yang disenangi maupun yang dibenci (Effendi, 2006: 67).

\section{SIMPULAN}

Berdasarkan hasil analisis data yang telah dijabarkan, dapat disimpulkan bahwa lirik lagu Melayu Jambi pada Album Mayang Mangurai karya Syahril Jahari terkandung niali religius yang berkaitan dengan hubungan manusia dengan Tuhan (Hablumminallah). Aspek (Hablumminallah) terdiri empat aspek yaitu, beriman kepada Allah, beribadah kepada Allah Swt., bersyukur kepada Allah Swt., dan bersabar menerima cobaan. Keempat aspek nilai religius yang berkaitan dengan hubungan manusia dengan Tuhan (Hablumminallah) terdapat 59 kutipan

Dalam Lirik Lagu Melayu Jambi pada Album Mayang Mangurai Karya Syahril Jahari, terdapat 28 kutipan aspek beriman kepada Allah Swt. terlihat dari lirik lagu seperti Berdoa, Meyakini Bahwa Hidup dan Mati di Tangan Tuhan, Meyakini Bahwa Allah Swt. dan Nabi Muhammad
Benar-Benar Ada. Kutipan yang berkaitan dengan aspek beriman kepada Allah Swt.

Dari kesemua kutipan ini teridentifikasi bahwa aspek yang paling dominan adalah aspek beriman kepada Allah Swt. sebanyak 28 kutipan, sedangkan aspek yang paling sedikit adalah aspek bersyukur sebanyak 5 kutipan. Dengan demikian apat disimpulkan bahwa bahwa irik lagu Melayu Jambi pada Album Mayang Mangurai Karya Syahril Jahari lebih menekankan kepada aspek beriman kepada Allah Swt..

\section{DAFTAR PUSTAKA}

Abdullah, Yatmi. (2006). Studi Islam Kontemporer. Jambi: Amzah.

Abdulsyani. (2015). Sosiologi Skematika Teori dan Terapan. Jakarta: Bumi Aksara.

Awe. (2003). Lirik Lagu. Available http://daemoo.blogspot.com/diakses ,e/jurnal/2020

Aziz, Abdul. (2013). Muslimah Cantik Aqidahnya Benar. Jakarta: Mirqat.

Effendi, A. (1996). Pelajaran Aqidah Akhlak Madrasah Tsanawiyah. Bnadung: Amrico.

Endraswara, Suwardi. (2013). Metodologi Penelitian Sastra. Yogyakarta: Caps (Center For Academic Publishing Service).

Ismawati. (2013). Pengantar Sastra. Yogyakarta: Ombak.

Khozin. (2013). Khazanah Pendidikan Agama Islam. Bandung: Remaja Rosdeakarya.

Kosasih. (2012). Dasar-dasar Keterampilan Bersasatra. Bandung: Yrama Widya.

Mahsun. (2006). Metode Penelitian Bahasa: Tahapan Strategi, Metode dan Tekniknya. Jakarta: Rajagrafindo Persada.

Muchtar, Jauhari Hari. (2005). Fikih Pendidikan. Bandung: Remaja Rosdakarya 
Nurgiyantoro, Burhan. (2012). Teori Pengkajian Fiksi. Yogyakarta: Gajah Mada University Press.

Rahima, A. (2017). Interpretasi Makna Simbolik Ungkapan Tradisional Seloko Hukum Adat Melayu Jambi. Jurnal Ilmiah Universitas Batanghari Jambi, 17(1), 250-267.

Rahima, A. (2017). Literature Reception (a Conceptual Overview). Jurnal Ilmiah Dikdaya, 6(1), 1-16.

Rahima, A. (2017). Nilai Nilai Religius Seloko Adat Pada Masyarakat Melayu Jambi (Telaah Struktural Hermeneutik). Jurnal Ilmiah Universitas Batanghari Jambi, 14(4), 1-8.

Rokhmansyah. (2014). Studi dan Pengkajian Sastra. Yogyakarta: Pustaka Pelajar.

Sapriani. (2018). Analisis Nilai-Nilai Religius Aspek Bersyukur dalam Novel Bidadari Bermata Bening Karya Habiburrahman El Shirazy. Jurnal Ilmiah Pendidikan Bahasa dan Sastra Indonesia http://aksara.unbari.ac.id/diakses, e/j urnal/2020

Siswantoro. (2010). Metode Penelitian Sastra. Yogyakarta: Pustaka Pelajar.

Sugiyono. (2016). Memahami Penelitian Kualitatif. Bandung: Alfabeta.

Tohirin. (2012). Metode Penelitian Kualitatif. Jakarta: Rajagrafindo Persada.

Wiyatmi. (2009). Pengantar Kajian Sastra. Yogyakarta: Pustaka Book Publisher.

Yusuf. (2003). Ilmu Pendidikan Islam. Jakarta: Amzah. 